Article

\title{
Rewriting Race, Gender and Religion in Toni Morrison's Song of Solomon and Paradise
}

\author{
Heather Hathaway
}

Department of English, Marquette University, Milwaukee, WI 53233, USA; heather.hathaway@marquette.edu

Received: 12 April 2019; Accepted: 19 May 2019; Published: 28 May 2019

\begin{abstract}
This article explores author Toni Morrison's creation of female spiritual leaders in her 1977 novel, Song of Solomon, and her 1998 novel, Paradise. I argue that she deliberately distorts Biblical imagery and narrative to rewrite women into the roles of spiritual agents rather than subjects, using irony and inversion, in Song of Solomon. She builds on this in Paradise by exploring the limitations of patriarchal orthodox Christian systems of social order and control by casting them in light of alternative spiritual beliefs, most notably Gnosticism.
\end{abstract}

Keywords: religion; Gnosticism; womanist theology; African American women; spirituality; Toni Morrison; Song of Solomon; Paradise; The Source of Self-Regard

Toni Morrison has long been occupied with the ways in which religious beliefs inform African American lives. She explained to Thomas Le Clair in a 1981 interview her motivations in writing Song of Solomon: "I used the biblical names to show the impact of the Bible on the lives of black people, their awe of and respect for it, coupled with their ability to distort it for their own purposes" (Morrison and Taylor-Guthrie 1994, p. 126). Fifteen years later, when discussing the challenges of writing Paradise in her 1996 essay, "God's Language," she asserted that religion was so central to African American culture that a "history that narrows or dismisses religion in both their collective and individual life, in their political and aesthetic activity, is more than incomplete-it may be fraudulent" (Morrison 2019, p. 248). But trying to convey to postmodern readers the significance of such a faith to black communities proved challenging. First, the writer, according to Morrison, must figure out how to "render religious language credibly and effectively in postmodern fiction without having to submit to a vague egalitarianism, or to a kind of late-twentieth-century environmental spiritualism, or to the modernist/feminist school of the goddess-body adored, or to a loose, undiscriminating conviction of the innate divinity of all living things, or to the biblical/political scholasticism of the more entrenched and dictatorial wings of contemporary religious institutions" (Morrison 2019, pp. 248-49). Second, the writer must also determine how to "narrate persuasively profound and motivating faith in and to a highly secularized, contemporary, 'scientific' world" (Morrison 2019, p. 249).

She takes up these challenges explicitly, first in her novel Song of Solomon, published in 1977, and again in Paradise, published twenty years later in 1997. In Song of Solomon, Morrison deliberately employs biblical language, imagery and allusion to subvert the gender- and race-based oppression that the Bible itself sanctions. I argue that Morrison uses irony, inversion and revision to manipulate female biblical stories and names in the novel, within the thematic context of the biblical "Song of Solomon," to redefine the relationship between gender, race and religion that emerged out of slavery.

In so doing, Morrison might be considered as anticipating the womanist theology and ethics that emerged in the 1980s. "Womanist," as a predominantly secular concept and term, was initially coined by writer Alice Walker in 1979 in her short story, "Coming Apart," and then later developed further in her 1983 collection, In Search of Our Mothers' Gardens. Walker defined a "womanist" as a "black feminist or feminist of color" who is "responsible," "in charge" and "serious"; who "appreciates 
and prefers women's culture, women's emotional flexibility ... and women's strength"; and who loves, among other things, "the Spirit," "struggle," "the Folk," "herself. Regardless," as well as all others, universally. ${ }^{1}$ While Walker's definition was predominantly secular, black female scholars of religion applied and broadened the concept to develop "womanist theology" as a corrective to the limitations of traditional white feminist and black theological frames. In 1987, Delores S. Williams, in "Womanist Theology: Black Women's Voices," defined womanist theology as a method grounded in a "multidialogical, liturgical, didactic" exploration of the "validity of female imagery and metaphorical language in constructing theological statements." ${ }^{2}$ The next year, scholar-activist Katie Geneva Cannon established, in Black Womanist Ethics (1988), the concept of "womanism" as an analytical rubric through which to explain and expose the systemic oppression experienced by black women in particular, and black people more generally. By 1989, a pivotal "Roundtable Discussion: Christian Ethic and Theology in Womanist Perspective" solidified womanist theology and ethics as central to African American, diaspora and religious studies. In this exchange, a stellar cohort of theologians and theorists consisting of Cheryl J. Sanders, Katie Cannon, Emilie M. Townes, M. Shawn Copeland, bell hooks, and Cheryl Townsend Gilkes further teased out the nuances of womanist theology to concretize it as an inclusive, justice-driven, love-based epistemology and ethics that foregrounds black women's commitments to standing against all forms of oppression to achieve communal wholeness and societal transformation. ${ }^{3}$

Morrison's Song of Solomon, published in 1977, predates this discussion, of course, though it embodies many of these same principles. Since Morrison does not refer to "womanism" or "womanist theology" herself when reflecting on her exploration of religion in her writings, I am reluctant to ascribe to her an intentional engagement in debates surrounding the definitions and purposes of a womanist theological or ethical epistemology. But I do consider convergences of the ideas in Song of Solomon and those of womanist theorists during the late 1970s and early 1980s to be products of a shared cultural milieu in which significant, often similar but not derivative, modes of cultural analysis and reasoning emerged. Song of Solomon both contributes to and reflects the cultural milieu from which womanist theology emerged as it challenges the stories the Bible tells African Americans generally and African American women, in particular. In the novel, Morrison crafts a complicated frame of Biblical names through which to create a new sacred text that places black female spiritual guides at the center of the male protagonist's figurative death and resurrection.

In Paradise, written twenty years later, the power and position of women as spiritual and ethical leaders also remains central. In this novel, however, Morrison pivots from using irony, inversion and revision to critique Biblical racism and misogyny and grounds herself instead in Gnostic ideas that emphasize female divinity and ways of "knowing," or gnosis, as correctives to the patriarchal hegemony and doctrine that was coming to define an emerging Orthodox Christianity. She describes herself, when writing Paradise, as trying to "write a religion-inflected prose narrative that [did] not rest its case entirely or mainly on biblical language" because she wanted to "make the experience and journey of faith fresh, as new and as linguistically unencumbered as it was to early believers, who themselves had no collection of books to rely on" (Morrison 2019, p. 253). In other words, in Paradise, she sought to create an opportunity for readers to witness the spiritual transcendence and even ecstasy experienced by Christ's early followers. The outcome of the two approaches Morrison takes in Song of Solomon and Paradise might be considered a "gospel of Toni" that preaches a womanist-inflected, spiritual and ethical way of being that exposes and critiques the misogyny undergirding orthodox Christianity and offers female spiritual leaders, grounded in mercy, communal wholeness, and love, as salvific alternatives. 


\section{Song of Solomon}

In Song of Solomon, Morrison casts biblically named women as the spiritual guides of the protagonist, Milkman Dead, to emphasize how black women, so rarely portrayed in the Bible, play pivotal roles in Milkman's formation and eventual salvation. Morrison comments on the importance of women's influence on Milkman in a 1983 interview with Nellie McKay:

I chose the man to make that journey because I thought he had more to learn than a woman would have. I started with a man, and I was amazed at how little men taught one another in the book. I assumed that all men ever learn about being men they get from other men. So that the presence of Pilate, and the impact that all the other women had on Milkman's life, came as a bit of a surprise to me. But it made it work out right, because there were two sets of information he needed to learn in order to become a complete human being. (Morrison and Taylor-Guthrie 1994, p. 154)

The two sets of information she refers to are gendered: Milkman can achieve balance and wholeness only by embodying what Morrison attributes to Pilate, "the best of that which is female and the best of that which is male" (Evans 1984, p. 344).

In order to give her female characters this power and influence, Morrison herself had to "distort" their biblical stories to make them meaningful in the context of Milkman's development. Through irony, inversion and revision, Morrison adapts the biblical stories associated with Rebecca, Hagar, Mary Magdalene, Paul's first letter to the Corinthians, Ruth and Pontius Pilate to expose simultaneously the sexism at the base of these biblical tales, as well as the inherent chauvinism of Milkman himself.

The characters Reba and Hagar, for instance, challenge both the Bible's and Milkman's notions of women as property. Playing on the story of Rebecca in the Old Testament, Morrison creates in Reba a character who wishes, to a radical degree, neither to possess nor to be possessed. While the biblical Rebecca was a virgin chosen by Abraham, the patriarch of Israel, to marry his son, Isaac, and maintain the family line, Morrison's Reba is the opposite: she is unabashedly no virgin, refuses to marry, and gives birth to a daughter who, as female and childless herself, preserves neither the maternal nor paternal family line. Unlike the biblical Rebecca who had no power outside the structures of marriage and motherhood and who was, indeed, defined as the property of first her husband and then her chosen son, Morrison's Reba is both untethered to a man and financially free (largely because she has no interest in money or owning anything). She gives away everything she ever owned, in fact, except for the diamond ring she won from Sears-a symbol that actually proves her autonomy rather than her dependence on a man.

Through Hagar, Reba's daughter, Morrison shows the perils of allowing oneself to be "owned" emotionally by another, as she again plays upon the themes of Hagar's story in the Bible. The biblical Hagar is an Egyptian slave of Sarah, the wife of Abraham. Because Sarah cannot bear children, she bids her husband to conceive a child, Ishmael, with the enslaved Hagar in order to carry on the family line and elevate Sarah's own standing from a barren woman to one with a child. Custom dictated that any child conceived by Abraham, with Sarah or a concubine, would be considered Sarah's and Abraham's. After Sarah unexpectedly conceives and gives birth to Isaac, however, she demands that Abraham banish Hagar and Ishmael to the desert to ensure that her own biological son is the sole heir to his father's fortune and property.

In Hagar's story in Song of Solomon, Morrison reiterates but twists the themes, subjects and agents of servitude, sexual exploitation and banishment that are found in Genesis. In her chapter, "A Mistress, A Maid, and No Mercy," minister Renita Weems argues that,

for black women, the story of Hagar in the Old Testament book of Genesis is a haunting one. It is a story of exploitation and persecution suffered by an Egyptian slave woman at the hands of her Hebrew mistress. Even if it's not our individual story, it's a story we've read in our mother's eyes ... after a hard day of work as a domestic. And if it is not our mothers' 
story, then it is certainly most of our grandmother's story. For black women, Hagar's story is peculiarly familiar. It's as if we know it by heart." ${ }^{4}$

While Weems expresses the resonance Hagar's narrative holds for black women generally, Morrison sharpens her commentary on oppression by making not a woman (Sarah) the agent of Hagar's misery, but rather by ascribing that role to Milkman, Hagar's own kin/cousin/lover.

When the two met, Milkman saw Hagar as his equal: "she was as strong and as muscular as he was" (Morrison [1977] 1987, p. 45). He fell in love with her and for twelve years enjoyed their sexual liaisons, but eventually he came to regard her as "the third beer. Not the first one, which the throat receives with almost tearful gratitude; nor the second, that confirms and extends the pleasure of the first. But the third, the one you drink because it's there, because it can't hurt, and because what difference does it make?" (Morrison [1977] 1987, pp. 92, 91). The biblical Hagar is a subject of jealous rivalry but Morrison's Hagar, as "not a real or legitimate girlfriend—not someone he might marry," was never fought over by "the various women [Milkman] dated 'seriously'" (Morrison [1977] 1987, p. 91). The biblical Hagar is initially welcomed as her husband's concubine but then shunned by her owner/"sister" Sarah, and Morrison's Hagar is initially welcomed as Milkman's concubine but then shunned by him, her "brother, cousin," as Pilate significantly refers to him. Moreover, when ending their relationship, Milkman treats Hagar like his prostitute or servant. He gives Hagar "a nice piece of money ..." " and a note thanking her for her years of service. "'Also, I want to thank you. Thank you for all you have meant to me. For making me happy all these years. I am signing this letter with love, of course, but more than that, with gratitude'" (pp. 43, 98, 99). By casting Milkman as Hagar's executioner (she eventually dies of despair), Morrison charges black men as complicit in the same dishonoring of their sisters/cousins/lovers that is perpetrated by the biblical Sarah and Abraham. The biblical story of Hagar is one of servitude, subjugation and exile grounded in racism and sexism. Morrison's story of Hagar signifies on these themes by portraying how the willingness to use and abuse another is not limited by race, time or place. ${ }^{5}$

Through Magdalene called Lena and First Corinthians, Morrison critiques biblical admonitions against female empowerment and sexuality. The figure of Mary Magdalene in the Bible has been interpreted for centuries as a redeemed whore, a portrayal that many scholars claim reinforced and justified the secondary role to which women have historically been relegated in orthodox Christianity. ${ }^{6}$ James Carroll summarizes this view:

Beginning with the threads of [the] few statements in the earliest Christian records, dating to the first through third centuries, an elaborate tapestry was woven, leading to a portrait of St. Mary Magdalene in which the most consequential note-that she was a repentant prostitute-is almost certainly untrue. On that false note hangs the dual use to which her legend has been put ever since: discrediting sexuality in general and disempowering women in particular. ${ }^{7}$

Paul's first letter to the Corinthians also "discredits sexuality" and "disempowers women" by requiring, among other things, a denial of sexual pleasure outside of marriage (1 Corinthians 6:12-20 and 7:1-16), women's silence (1 Corinthians 14:34) and women's submissiveness (1 Corinthians 11:4). Morrison calls into question all of these principles by casting Lena as the agent, and First Corinthians as the embodiment of female voice, authority and sexuality.

4 (Weems 2005, p. 1).

5 For a discussion about the ways in which violence toward black women in particular constitutes a unique form of social and personal sin, see womanist theologian Delores S. Williams (1995).

6 See K.L. (King 2003; Esther DeBoer 2004; Christopher Tuckett 2007; Brock 2003).

7 www.smithsonianmag.com/history/who-was-mary-magdalene-119565482/\#FD4TecXcCKwrjv6G.99. This article helpfully teases out the references to numerous biblical women named Mary in an effort to come to a closer understanding of who, historically, Mary of Magdalene might have been. 
Through Lena, Morrison challenges the passivity ascribed to Mary Magdalene in the Bible by casting her more along the lines of the Mary Magdalene presented in the gnostic gospels. Gnosticism is a modern term that refers to a variety of syncretic religious movements present during the first and second centuries AD. The "gnostic gospels," with which Morrison is obviously familiar given that she uses excerpts from them as epigraphs to both Jazz (1992) and Paradise (1997), were revealed upon the discovery of what has become known as the Nag Hammadi Library, a set of ancient texts found buried in an earthen jar in Egypt in 1945. These are attributed to figures other than the authors of the four gospels that have been canonized, Matthew, Mark, Luke and John, and many challenge the accepted narrative of male authority found in the New Testament. For example, the gnostic Mary Magdalene is not a prostitute but rather is singled out by Jesus for special teaching, portrayed as his most cherished disciple and the "apostle of the apostles," and considered by some, as scholar Karen King recently documented with a Coptic papyrus, to be Jesus' wife (King 2014). The Gospel of Philip describes Mary Magdalene as

... the companion of the [Savior] ... [Christ loved] her more than [all] the disciples, and used to kiss her [often] on her [mouth]. The rest of [the disciples were offended] ... They said to him, "Why do you love her more than all of us?" The Savior answered and said to them, "Why do I not love you as (I love) her?". (Pagels 1979, p. xv)

While both the biblical and gnostic Magdalenes are present at the crucifixion and the resurrection, the biblical Mary Magdalene is described as a lowly woman to whom Christ first manifests himself, whereas the gnostic Mary Magdalene is depicted as Christ's chosen spokesperson to announce his rebirth and to tell Peter and the other apostles about his command to them to preach the gospel. Morrison's Lena recalls the empowered position of the gnostic Mary Magdalene, particularly in the culminating scene of Part One of the novel in which Lena claims her voice and asserts her gendered authority to her brother.

Morrison begins Lena's speech by referencing directly the false virgin-whore dichotomy that has defined Jesus' mother, Mary, and the biblical Mary Magdalene for centuries. In reference to her father, Lena states, "First he displayed us, then he splayed us. All our lives were like that: he would parade us like virgins through Babylon, then humiliate us like whores in Babylon" (Morrison [1977] 1987, p. 216). Next, Morrison evokes the confrontation between Mary Magdalene and Peter after Christ's resurrection. In the biblical scene, Peter questions Mary Magdalene's legitimacy, as a woman, to serve as Christ's messenger. Just as the gnostic Mary Magdalene challenged Peter's claims to a superiority based solely on his gender, Morrison portrays Magdalene, called Lena, as similarly calling Milkman to task. $^{8}$

"Our girlhood was spent like a found nickel on you ... And to this day, you have never asked one of us if we were tired, or sad, or wanted a cup of coffee. You've never picked up anything heavier than you own feet, or solved a problem harder than fourth-grade arithmetic. Where do you get the right to decide our lives? ... I'll tell you where. From that hog's cut that hangs down between your legs". (p. 215)

Lena further calls out Milkman's motives for hitting his father, Macon, in alleged defense of his mother, Ruth: "You think because you hit him once that we all believe you were protecting her. Taking her side. It's a lie. You were taking over, letting us know you had the right to tell her and all of us what do to" (pp. 215-16). But Morrison refuses Milkman, and by implication all men, this presumed but unearned authority grounded solely in their gender. By casting Lena as the authoritative gospel preacher who sends Milkman on his journey toward salvation, and by evoking Peter's and Mary's confrontation, Morrison rejects the silent and subservient position to which women are relegated in the Bible.

8 The confrontation between Peter and Mary Magdalene is also depicted in the gnostic texts, The Gospel of Thomas, Pistis Sophia, and The Gospel of the Egyptians. 
Through the character of First Corinthians, Morrison challenges Paul's teachings on sexuality. First Corinthians is an unemployed, paternally dependent, virginal woman who lives in the sterile home of her father. She is saved from this by Porter, a lower-class "Southside" man whom the Dead family deemed unworthy of her. After all, "she was First Corinthians Dead, daughter of a wealthy property owner and the elegant Ruth Foster, granddaughter of the magnificent and worshipped Dr. Foster" (Morrison [1977] 1987, pp. 197-98). Porter and Corinthians keep their affair a secret because the 40-year-old woman is afraid to reveal it to the patriarchs of the family, her father and brother. Consequently, Porter decides to end the relationship but

... in a panic, lest he shift gears and drive away, leaving her alone in the street, Corinthians climbed up on the fender and lay full out across the hood of the car. She didn't look through the windshield at him. She just lay there, stretched across the car, her fingers struggling for a grip on the steel. She thought of nothing. Nothing except what her body needed to do to hang on, to never let go. Even if he drove off at one hundred miles an hour, she would hang on. (Morrison [1977] 1987, p. 199)

Porter relieves Corinthians from her metaphorical "cross" on the car and the two finally consummate their love in the tiny room he rents from her father. Morrison goes so far as to imply that Corinthians has been symbolically reborn as a result: "standing there, barefoot, her hair damp with sweat and sticking to her cheeks like paint, she felt easy. In place of vanity she now felt a self-esteem that was quite new" (p. 201). This rendering of a figurative crucifixion and rebirth implies that Morrison suggests that life is found in the union of the body and the soul, in contrast to Paul's dualist contentions that the spiritual is more important than the physical and that sexuality outside marriage is sinful. ${ }^{9}$

Finally, Morrison distorts the Book of Ruth's themes of female love and devotion to subvert biblical patrilineality by linking Pilate to both Naomi and the goel, Boaz, in Ruth's biblical tale. By virtue of Levirite laws, the biblical Ruth's son, Obed, is considered also to be Naomi's, and so, too, does Ruth Foster Dead consider Pilate to be Milkman's other mother. Ruth explains to Milkman that, when Macon insisted that she abort their baby, "Pilate helped me stand him off. I wouldn't have been strong enough without her. She saved my life. And yours, Macon. She saved yours too. She watched you like you were her own" (pp. 125-26). Pilate subsequently watches over Milkman's crib until Macon banishes her from the household. Later, Pilate rescues Milkman from jail and, most importantly, serves as his spiritual guide on his journey toward balance. ${ }^{10}$

But more subversive than Pilate's sharing Ruth's role as mother is Morrison's portrayal of her supplanting the paternal role of Macon as well. Deuteronomy 25:5-6 describes the role of the goel: "when brothers live on the same property and one of them dies without a son, the wife of the dead man may not marry a stranger outside the family. Her brother-in-law is to take her as his wife, have sexual relations with her, and perform the duty of a brother-in-law for her. The first son she bears will carry on the name of the dead brother, so his name will not be blotted out from Israel" (Christian Standard Bible). This does, of course, ensure that women and women's bodies remain in control of men, further solidifying patriarchal privilege. But again, Morrison turns this on its head. In Song of Solomon, Macon has no male kin, only his sister, Pilate. Though not dead literally, Macon's name is Dead and his relationship with his wife is dead as well. Morrison alludes to the Jewish law of the goel but feminizes it by casting Pilate in the role. By coercing her figuratively dead brother, through conjure, to have sex with Ruth against his will, she acts symbolically as Milkman's progenitor. "You'll get pregnant ... He ought to have a son. Otherwise this be the end of us" (p. 125). Through Pilate's intervention, Milkman is born to carry on the family name.

9 See womanist theologian Kelly Brown Douglas' Sexuality and the Black Church (Orbis, 1999) for a view of sexuality as God's gift to an embodied humanity/divinity that allows for healing, loving and life-sustaining relationships.

10 Perhaps Ruth's maiden name of Foster is intended to signal her role as "foster" mother in relation to Pilate's more influential presence. 
Moreover, the definition of goel is "redeemer" and, not surprisingly, Morrison depicts Pilate as the one who ultimately leads the way for Milkman's redemption. Playing on Christ's crucifixion by Pontius Pilate on the cross, which is often referred to as a tree in the Bible, Morrison imbues Pilate with qualities symbolizing a tree of life, not death. ${ }^{11}$ According to Debra Walker King, Morrison fictionalized a tradition practiced in Morrison's own family when she portrays Pilate's illiterate father selecting his daughter's name blindly from the Bible (D.W. King 1998, p. 87). ${ }^{13}$ Jake is described as seeing "a group of letters that seemed to him strong and handsome." He saw in them "a large figure that looked like a tree hanging in some princely but protective row of smaller trees" and so he chose the name, "Pilate," for his baby girl (p. 118). Whereas Pontius Pilate sent alleged miscreants to be crucified on a "tree," Morrison portrays Pilate Dead as providing the tree-like shelter to her family that her father initially saw in the letters shaping her name. She further emphasizes this association by depicting Pilate's house as surrounded by "four huge pine trees," the needles of which Pilate chewed and with which she stuffed her mattress, causing her brother Macon to remember her as always "smelling like a forest" (p. 27). Morrison describes Pilate as, when cooking, "sway[ing] like a willow over her stirring" (p. 30). She invests Milkman with the thought that Pilate looked "like a tall black tree" when he first meets her (p. 39). Finally, Morrison transforms Pilate, when she is attempting to save Hagar from death, into a "divi-divi tree beaten forward by a wind always blowing from the same direction. Like the tree, [Pilate] offered [Hagar] all [she] had: love murmurs and a protective shade" (p. 315). By naming Pilate after Christ's crucifier but imbuing her with living arboreal qualities, Morrison symbolically and semiotically subverts the association of Pilate Dead with Pontius Pilate's crucifixion of Christ on a tree/cross.

In fact, Morrison casts Pilate as Christ-like herself and, in so doing, offers a final rewriting of biblical racial and gender hierarchies. The savior of this novel is a black female ancestor whose very presence preserves the past, maintains the present, and promises a future. According to Morrison, African American fiction is distinguished from other types of writing because "there is always an elder there. And these ancestors are not just parents, they are sort of timeless people whose relationships to the characters are benevolent, instructive, and protective, and they provide a certain kind of wisdom" (Evans 1984, p. 343). An essential element of Pilate's wisdom lay in her understanding of the need for balance: between male and female influence and authority, between love and hate, between the vengeance of the Seven Days and the redemption invited by mercy, between Old Testament and New Testament forms of justice. Morrison argues that, if "that balance is disturbed, if it is not nurtured, and if it is not counted on and if it is not reproduced ... we are, in fact, lost" (Evans 1984, p. 344). Though Pilate is killed at the end of the novel, she has already saved Milkman by passing on her wisdom, by nurturing in him an awareness of the need for "balance" (note that when Milkman finally understands his family story he no longer limps, symbolizing his own newly found balance), thus ensuring that the knowledge of the ancestor has been "reproduced," not "lost."12

While Morrison rewrites black women into the central roles of spiritual guides, gospel preacher, and savior in Song of Solomon, she draws upon another paradigm for women in relation to Christianity in Paradise. To critique the patriarchal structure of orthodox Christianity, Morrison creates a female leader in Consolata (Connie) through whose guidance the women at the convent, some women in the town of Ruby, and even one of the town's patriarchs come to a knowledge of the divine within themselves and, as such, of a spiritual divinity as well. But showing the depth of these experiences required that Morrison not use biblical references in Paradise. In Paradise, simply "layer[ing] religiosity onto an existing canvas of migration and the quest for citizenship, or ... tip[ping] one's hat to characters whose belief is unshakable" was insufficient, in her mind (Morrison 2019, p. 248).

11 https://forwhatsaiththescriptures.org/2015/04/26/jesus-hanged-on-a-tree/.

12 Of course, one could also interpret Pilate's death at Guitar's hands as symbolic of Christ as well in that she died so that Milkman might live. This reading depends on how the final scene of the novel is interpreted: does Milkman literally die "in the killing arms of his brother" or does, "in surrendering to" and "riding the air," does he become transcendent? 
The novel's time frame, from 1908 to 1976, and the history of its population, former and children of former slaves, require me to rely heavily on the characters' reserves of faith, their concept of freedom, their perception of the divine, and their imaginative as well as organizational/administrative prowess. For like many, but not all, deliberately, carefully constructed nineteenth-century communities, a deeply held and wholly shared belief system was much more vital to the enterprise than was physical endurance, leadership, and opportunity .... Therefore, among the difficulties before me is the daunting one of showing not just how their civic and economic impulses respond to their religious principles but how their everyday lives were inextricably bound with those principles. (Morrison 2019, p. 248)

In this novel, she needed, in her words, "to construct a work in which religious belief is central to the narrative itself" (Morrison 2019, p. 248).

To do so, she creates the town of Ruby as emblematic of a patriarchal, orthodox Christianity and the Convent as its antithesis. Ruby is led by the male Morgan twins, significantly name Steward and Deacon, and populated by several other god-fearing men and their families. This group, along with their predecessors, have fled racism, colorism and general persecution to create a "paradise" on earth. Here, deference to God's authority is typified in the statement on the Oven-an artifact that historically served as the center of the community- "Beware the Furrow of His Brow." In Ruby, the streets are named after the canonized gospel writers, St. Mark, St. Matthew, St. Luke and St. John. Not surprisingly, given the confrontation between Peter and Mary Magdalene about who had rightful authority to announce Christ's call to preach the gospel, "when a fifth street was needed, it was named St. Peter" (Morrison 1998, p. 114). Ruby, according to Morrison, "is all about its race" and its history: "preserving it, developing powerful myths of origin, and maintaining its purity" (Morrison 2019, p. 274). Life itself, not just religion, is classified into good and evil, insider and outsider, conformist and noncomformist, male and female, and friend and foe.

Ruby's opposite can be found in the community of women who live seventeen miles outside of town in "the Convent." They are a family defined not by bloodlines but by choice. Belonging is not predicated on shared history or ideology but by the women's common experiences of being expelled or escaping from somewhere else. In contrast to the order and religious principles that pervade Ruby's economic, civic and daily life, the Convent is characterized by a clashing of the sacred and profane: the building was once "an embezzler's folly. A mansion where bisque and rose-tone marble floors segue into teak ones. Isinglass holds yesterday's light and patterns walls that were stripped and whitewashed" when it was taken over by Catholic nuns to create an Indian Boarding School (Morrison 1998, p. 4). Statues of saints stand alongside naked cherubs engaging in bacchanalia and brass mermaids holding up bathtubs with their upturned, lush bosoms. Finally, whereas Ruby is focused on preserving its history, the women in the Convent strive to make meaning of traumatic pasts in the present in order to create free futures for themselves.

Morrison explains that she set up "an all black community, chosen by its inhabitants, next to a raceless one, also chosen by its inhabitants" to shift the focus from "traditional black/white hostilities" to "the nature of exclusion, the origins of chauvinism, the sources of oppression, assault, and slaughter" (Morrison 2019, pp. 273-74). The entire book is a meditation on these conflicts from multiple angles, with gender, generation, values, ethics, and personal identity, among them. At stake, according to Morrison, is the "struggle over history" - the same battle, I argue, engaged in by the world of early Christianity. "Who will tell and therefore control the story of the past?" she asks. "Who will shape the future? ... What is manhood? Womanhood? And finally, most importantly, what is personhood?" (Morrison 2019, p. 274). To this, I will add, who is given the authority to decide?

To explore these questions, Morrison compares the orthodox Christian practices and beliefs in the town of Ruby to a variety of alternate spiritual beliefs, many of which are grounded in gnosis. Gnosticism generally holds that the answers to these questions come from the self. At the foundation of these beliefs is gnosis, or "knowledge." Scholar (and Morrison's close colleague at Princeton) Elaine Pagels explains, 
For as those who claim to know nothing about ultimate reality are called agnostic (literally, "not knowing"), the person who does claim to know such things is called gnostic ("knowing"). But gnosis is not primarily rational knowledge. The Greek language distinguishes between scientific or reflective knowledge ("He knows mathematics") and knowing through observation or experience ("He knows me"), which is gnosis. As the gnostics use the term, we could translate it as "insight," for gnosis involves an intuitive process of knowing oneself. And to know oneself, they claimed, ... at the deepest level is simultaneously to know God. (Pagels 1979, p. xix)

The gnostic teacher, Monoimus, directed followers, in fact, to "abandon the search for God ... Look for him by taking yourself as the starting point. Learn who it is within you who makes everything his own and says, 'My God, my mind, my thought, my soul, my body.' Learn the sources of sorrow, joy, love hate ... If you carefully investigate these matters, you will find him in yourself" (Pagels 1979, pp. $\mathrm{xix}-\mathrm{xx}$ ). Though allusions to Gnosticism seem to pervade the novel, three events, in particular, seem intentionally modeled on gnostic beliefs.

The first involves Consolata bringing Scout (not his brother, "Easter," oddly enough) back to life after a car accident. Consolata, having been adopted and raised by nuns, is a firm follower of Catholic doctrine but her friend, Lone DuPres, who is also an outsider to the town of Ruby, is open to "practicing," which Consolata finds heretical. Lone tries to help her see that "faith" and "practicing" are not antithetical to one another.

Lone didn't visit often, but when she did she gave Consolata information that made her uneasy. Consolata complained that she did not believe in magic; that the church and everything holy forbade its claims to knowingness [my emphasis] and its practice. Lone wasn't aggressive. She simply said, "Sometimes folks need more."

"Never," said Consolata. "In my faith, faith is all I need."

"You need what we all need: earth, air, water. Don't separate God from His elements. He created it all. You stuck on dividing Him from His works. Don't unbalance his world." (Morrison 1998, p. 244)

Morrison's direct reference to "knowingness" seems intentionally to allude to Gnosticism. Lone becomes the "lone" voice who is able to urge Connie to embrace beliefs wider than those to which Catholic orthodoxy has limited her and to "practice" to save another's life.

Connie resists this thinking until Soane and Deacon's son is near death in a car crash. In response to Lone's plea to "go inside him. Wake him up ... Step in. Just step on in. Help him, girl!" Consolata "looked at the body and without hesitation removed her glasses and focused on the trickles of red discoloring his hair."

She stepped in. Saw the stretch of road he had dreamed through, felt the flip of the truck, the headache, the chest pressure, the unwillingness to breathe ... Inside the boy she saw a pinpoint of light receding. Pulling up energy that felt like fear, she stared at it until it widened. Then more, more so air could come seeping, at first, then rushing, rushing in. Although it hurt like the devil to look at it, she concentrated as though the lungs in need were her own. Scout opened his eyes, groaned and sat up. (p. 245)

Morrison's description of this scene calls forth the gnostic belief that "each of us has a spark of divinity within, which can be fanned into a fire through which we can each partake of the nature of the true and highest God" (Smith 2009, p. ix). She goes so far as to name it "in sight," if not gnosis, when she describes how Connie found a way to reconcile herself to it that would neither "offend Him or place her soul in peril."

It was a question of language. Lone called it 'stepping in.' Consolata said it was 'seeing in.' Thus the gift was 'in sight.' Something God made free to anyone who wanted to develop it. 
It was devious but it settled the argument between herself and Lone and made it possible to accept Lone's remedies for all sorts of ills and to experiment with others while the "in sight" blazed away. The dimmer the visible world, the more dazzling her "in sight" became. (Morrison 1998, p. 247)

By investing Connie with the ability to call forth the "spark of divinity" within Scout (and, later, Mary Magna as well), to "fan it into a fire" and save his life, Morrison suggests Consolata is gifted with gnosis or "insight" that emerged from "an intuitive process of knowing" herself and her abilities.

Morrison follows this event with a second apparent allusion to gnostic beliefs in the ritual of cleansing and rebirth that the women undergo in the cellar. After a symbolic "last supper" and under the direction of a seemingly resurrected Consolata, the women follow Jesus' teaching in the gnostic Gospel of Thomas in which he directs believers to "bring forth what is in you, what you bring forth will save you. If you do not bring forth what is within you, what you do not bring forth will destroy you" (Pagels 1979, p. 126). To do so, Connie draws crime scene-like templates of each woman on the floor and the women then lie in them. Collectively, over a period of days, from these metaphorical coffins, they articulate their deepest wounds.

That is how the loud dreaming began. How the stories rose in that place. Half-tales and the never-dreamed escaped from their lips to soar high above guttering candles, shifting dust from crates and bottles. And it was never important to know who said the dream or whether it had meaning. In spite of or because their bodies ache, they step easily into the dreamer's tale ... In loud dreaming, monologue is no different from a shriek; accusations directed to the dead and long gone are undone by murmurs of love ... Life, real and intense, shifted to down there in limited pools of light.... (Morrison 1998, pp. 264-65)

In the process, "with Consolata in charge, like a new and revised Reverend Mother, feeding them bloodless food and water alone to quench their thirst, they altered" (p. 265).

"In bringing forth what was within them," in learning the sources of their "joy, sorrow, love, hate" as directed by Monoimus, did the women experience death and resurrection? Whereas orthodox Christianity insisted that "the apostles alone held definitive religious authority, and that their only legitimate heirs are priests and bishops who trace their ordination back to that same apostolic succession," gnostic Christians rejected this, based largely on a central difference in how the two groups interpreted Christ's resurrection. Orthodox Christians believed Christ was literally resurrected, in the flesh, and then ascended to heaven. Only those apostles who physically encountered him in his resurrected state were allowed to preach his teachings. As Pagels explains, "[e]ven today the pope traces his-and the primacy he claims over the rest-to Peter himself, 'first of the apostles,' since he was 'first witness to the resurrection'" (Pagels 1979, p. 11).

Gnostic Christians, on the other hand, in addition to asserting that a woman, Mary Magdalene, was Christ's chosen apostle and the first to witness the resurrection, also believed the resurrection to be symbolic. They did not see it as a unique event that took place in the past and was witnessed only by a chosen few; instead, they saw it as symbolizing how Christ's presence could be experienced by anyone, at any time. The difference between understanding Christ's resurrection literally or symbolically gets to the heart of Morrison's self-described goals, when writing Paradise, to examine "the nature of exclusion, the origins of chauvinism, the sources of oppression, assault, and slaughter (Morrison 2019, pp. 273-74). A literal interpretation is inherently exclusive in that it ensures that all religious "authority derives from certain apostles' experience of the resurrected Christ," thus paving the way for a patriarchal, "apostolic" church governance (Pagels 1979, p. 10). A spiritual interpretation is inherently inclusive in that the possibility of spiritual rebirth is open to all. The author of the gnostic Treatise on Resurrection explains "that ordinary human existence is spiritual death. But the resurrection is the moment of enlightenment: 'It is ... the revealing of what truly exists ... and a migration (metabole - change, transition) into newness'" (Pagels 1979, p. 12). Pagels explains that "gnostic accounts often mention how the recipients respond to Christ's presence with intense emotions-terror, awe, distress, joy," 
and that gnostic writers "respect—even revere—such experiences, through which spiritual intuition discloses insight into the nature of reality" (Pagels 1979, p. 12).

Morrison does not elaborate on what "altering" means in the context of the ritual in the cellar except to say that, following it, Soane was startled to notice "how calmly themselves they all seemed," how "the women were no longer haunted" (Morrison 1998, p. 266). Certainly, some type of rebirth seems to be the consequence of the "altering." Shortly after the completion of the template ritual, Morrison depicts the women as symbolically baptizing themselves in a rainfall.

Gathered in the kitchen door, first they watched, then they stuck out their hands to feel. It was like lotion on their fingers so they entered it and let it pour like balm on their shaved heads and upturned faces. Consolata started it; the rest were quick to join her. There are great rivers in the world and on their banks and the edges of oceans children thrill to water. In places where rain is light the thrill is almost erotic. But those sensations bow to the rapture of holy women dancing in hot sweet rain. (p. 283)

Bearing the shaved heads of female Buddhist monks, these are "holy women" who know themselves and, in so doing, have found the divine in themselves and one another.

Having set up Ruby to represent an orthodox Christian community that thought it was doing good by following the ways of the Bible, insulating itself from danger, and holding evil at bay, Morrison reveals the consequences of such thinking. She states that in the novel, she chose "not only to explore the idea of paradise, but to interrogate the narrow imagination that has conceived it" (Morrison 2019, p. 279). In Paradise, that narrow imagination belongs to the patriarchs of Ruby who cannot tolerate the feminine consecration of the women in the Convent, these "bodacious black Eves" whom they perceived to be "unredeemed by Mary" and filled with "female malice" (Morrison 1998, p. 18). "Before those heifers came to town," says one of them as they plan the massacre, "this was a peaceable kingdom. The others before them at least had some religion. These here sluts out there never step foot in a church and I bet you a dollar to a fat nickle they ain't thinking about one either. They don't need men and they don't need God" (Morrison 1998, p. 276). So, in a town whose men prided themselves about the fact that their women "were not prey," the male town leaders, headed by patriarchs Deacon and Steward, hunted down the Convent women and, with the "odor of righteousness" and "God at their side, ... t [ook] aim. For Ruby" (Morrison 1998, p. 18).

If Morrison begins Paradise with the certainty of murder-the very first line of the novel is "they shoot the white girl, first" - she closes the novel with the uncertainty of death, just as she did in Song of Solomon. In Song of Solomon, protagonist Milkman leaps off a cliff toward his "main man," Guitar, knowing full well that Guitar has been trying to kill him. But Morrison tells us that "it did not matter which one of them would give up his ghost in the killing arms of his brother ... For now [Milkman] knew what [his ancestor] Shalimar knew: if you surrendered to the air, you could ride it" (Morrison [1977] 1987, p. 337). Milkman's journey has led him to a place of self-knowledge, atonement, and rebirth. With the help of the female spiritual guides to lead him, by surrendering the power to control and possess, he achieves salvation. Morrison closes Paradise with similar ambiguity about what constitutes life and death: when Roger Best, the town's undertaker, goes to the Convent to retrieve the bodies of the slain women, he finds none. The final pages of the novel portray the women reuniting with the family members who wounded them, in acts of forgiveness, reconciliation and redemption. Are we to interpret these "resurrections" as literal or symbolic? Does it matter? In creating these ambiguities, Morrison importantly gives-or challenges-her readers with the authority to decide not only what is manhood, womanhood and personhood, as she describes in her essay, "The Trouble with Paradise," but also what defines virtue and vice, sacred and profane, justice and injustice, inclusive and exclusive, and life-giving and life-taking.

These two novels suggest that the "gospel of Toni" considers redemption as the outcome of engaging in the difficult and often painful processes of self-knowledge and self-forgiveness. It is a "gospel" that preaches inclusion, equality and communal wholeness as the goal and defines love and 
mercy as the means by which to attain it. Through irony, inversion and revision of canonical biblical narratives and orthodox Christian histories that position men at the center of a patriarchal church, in Song of Solomon and Paradise, Morrison offers a womanist-inflected, spiritual and ethical alternative in which women, and black women in particular, act as a salvific force in a vindictive and vengeful world. That is quite a corrective gospel, indeed.

Funding: This research received no external funding.

Conflicts of Interest: The author declares no conflict of interest.

\section{References}

Brock, Ann Graham. 2003. Mary Magdalene, The First Apostle: The Struggle for Authority. Cambridge: Harvard UP. DeBoer, Esther. 2004. The Gospel of Mary: Beyond a Gnostic and a Biblican Mary Magdalene. London: Continuum. Evans, Mari. 1984. Black Women Writers (1950-1980): A Critical Evaluation. Garden City: Anchor Press/Doubleday. King, Debra Walker. 1998. Deep Talk: Reading African-American Literary Names. Charlottesville: University Press of Virginia.

King, Karen L. 2003. The Gospel of Mary of Magdala: Jesus and the First Woman Apostle. Santa Rosa: Polebridge Press.

King, Karen L. 2014. "Jesus Said to them, 'My Wife...'”: A New Coptic Papyrus Fragment. Harvard Theological Review 107: 131-59. [CrossRef]

Kirk-Duggan, Cheryl. 2014. Womanist Theology as a Corrective to African American Theology. Available online: http://0-www.oxfordhandbooks.com.libus.csd.mu.edu/view/10.1093/oxfordhb/9780199755653.001. 0001/oxfordhb-9780199755653-e-019 (accessed on 17 May 2019).

Morrison, Toni, and Danielle Taylor-Guthrie. 1994. Conversations with Toni Morrison. Jackson: University Press of Mississippi. Morrison, Toni. 1987. Song of Solomon. New York: Knopf. First published 1977.

Morrison, Toni. 1998. Paradise. New York: Knopf.

Morrison, Toni. 2019. The Source of Self-Regard: Selected Essays, Speeches and Meditations. New York: Alfred Knopf. Pagels, Elaine. 1979. The Gnostic Gospels. New York: Random House.

Smith, Andrew Phillip. 2009. A Dictionary of Gnosticism. Wheaton: Theosophical Publishing House.

Tuckett, Christopher. 2007. The Gospel of Mary. Oxford: Oxford University Press, Electronic Resource. Available online: http://gnosis.org/library/marygosp.htm (accessed on 17 May 2019).

Walker, Alice. 1983. In Search of Our Mothers' Gardens: Womanist Prose. San Diego: Harcourt, Brace, Jovanovich, pp. xi-xii.

Weems, Renita. 2005. Just a Sister Away: Understanding the Timeless Connection Between Women of Today and Women in the Bible. West Bloomfield: Walk Worthy Press.

Williams, Delores S. 1987. Womanist Theology: Black Women's Voices. Christianity and Crisis 47.

Williams, Delores S. 1995. Sisters in the Wilderness: The Challenge of Womanist God-Talk. Maryknoll: Orbis. 